\title{
Antecedents of Behavioral Intentions on Online Travel Agent Company: Comparison between Generation X and Millennial
}

\author{
Faisal Arsya Rakhmada ${ }^{1}$, and Sri Rahayu Hijrah Hati ${ }^{1}$
}

\begin{abstract}
The number of internet users in Indonesia has grown at the unbelievable rate. There is no exception with the growth rate of the online travel agent users in Indonesia. When making online transaction, including via online travel agent, consumers are faced with uncertain situations. The uncertain situations could grow increasingly critical when consumers have to share sensitive personal information in the transaction process. In this context, the importance of building and maintaining trust becomes very important to online marketers as numerous studies have shown that the lack of trust is one of main reasons for consumers' hesitancy to online shopping. The evidence has shown that trust could reduce the perceived risks and thereby determines success or failure of e-vendors. The research objective is to analyze the antecedents of behavioral intentions on online travel agent company. Also to see whether the trust formation between generation $X$ and Millennial has difference. The research is based on online surveys conducted with convenience samples from two different generation. The results have shown a strong relationship between initial trust towards online travel agent and consumers' behavioral intentions. The results suggest that there's no difference between two generations on the formation trust and behavioral reactions. Both Gen $X$ and Millennial seen the risks and trust of using online travel agent in the same way. Both generation willing to give personal information to online travel agent.
\end{abstract}

Keywords-Online Travel Agent, Behavioral Intentions, Trust Propensity, Familiarity, Web Risk.

\section{INTRODUCTION}

Based on reports released by the Indonesian Internet Service Providers Association (APJII) in 2017, around 143 million Indonesians have been connected to the internet. People aged from 19 to 34 became the largest contributor with 49.52 percent. While the second highest number, or reaching 29.55 percent, is occupied by people aged 35 to 54 years. Based on those facts, this study included those two age groups as the main respondents. Based on data obtained from a survey conducted by DailySocial in 2018, it was seen that almost $90 \%$ of respondents said they had traveled out of town or abroad in the past 6 months. Then more than $75 \%$ of respondents have traveled out of town or abroad as much as less than 6 times in the last 6 months.

\footnotetext{
${ }^{1}$ Faisal Arsya Rakhmada and Sri Rahayu Hijrah Hati are with Departement of Economy and Business, University of Indonesia, Jakarta, 10430, Indonesia. E-mail: hijrahhati@gmail.com.
}

Still from the same survey, $71.44 \%$ of respondents have used online travel agent services in the past six months. Between $50 \%$ and $70 \%$ of respondents use Traveloka and / or Tiket.com to reserve airplane tickets, train tickets, and / or hotel rooms. Traveloka ranks first as the most popular online travel agent for consumers. Referring to this, this research makes Traveloka the object of research.

When making online purchases, consumers are faced with uncertain situations, and this can increase consumer concerns along with the personal information that consumers must provide when making a purchase[1][1]. Based on this, it is important for companies to be able to maintain consumer trust. There are many studies that show that a lack of trust is one of the main causes of consumers being reluctant to shop online [1], [2].

Truong \& Simmons, 2010 say that online marketing which is viewed negatively, can lead to negative views on the brand and can affect the trust that is owned by the millennial generation towards the brand. Trust has become an important part that can reduce the risks felt by consumers, and it can determine whether a company will succeed or fail [4]-[6].

Consumer trust can be formed if consumers satisfy with the products and services provided by the company. Henning-Thurau et al. (2002) argue that satisfaction is a key element in the process that occurs between companies and consumers [7]. Satisfaction is a key factor to better understand consumer behavior and also increase the likelihood of consumers making repeat purchases. If the company succeeds in increasing customer satisfaction, the company will be able to increase consumer loyalty [8][11].

In addition to influencing the satisfaction felt by consumers, consumer trust in a brand will also greatly influence behavioral intentions for the brand. Behavioral intentions can be divided into two categories, namely behavioral intentions that benefit the company and behavioral intentions that harm the company [12]. Examples of beneficial behavioral intentions such as positive WOM, willingness to pay more expensive prices, spend more money on a brand and also remain loyal to the brand. While behavioral intentions that are detrimental for example, such as spreading WOM negatives even to take legal action if consumers feel that a brand has harmed them [12]. 


\section{LITERATURE REVIEW}

\section{A. Initial Trust}

Rousseau et al. (1998) concluded that there are three main phases in the process of forming trust, namely: the first phase is building trust, the second phase is stability of trust and the third phase is dissolution or support of trust [13]. Trust is willingness for the benefit of other parties after the first interaction [5]. While the initial trust is temporary and there is no information or interaction that existed before [14].

\section{B. Behavioral Intentions}

According to Zeithaml et al, (1996), behavioral intentions are a sign of whether consumers will continue to trust and use a brand or will try another brand [15]. Behavioral intentions are considered as an important factors that can explain the consumer's strong intention to be able to do a certain action [16]. Behavioral intentions can be divided into two categories, behavioral intentions that benefit the company and behavioral intentions that harm the company [12]. Examples of positive behavioral intentions that can be done by consumers, such as positive WOM, the willingness to pay at a higher price, spend more money on a brand and also remain loyal to the brand. While behavioral intentions that are detrimental to the company for example such as spreading negatives WOM or even take legal action if consumers feel that a brand has harmed them [12].

According to Schoorman et al (2007), there are three characteristics of consumers that can reinforce that consumer personality can influence the process of forming initial trust between consumers and a brand [17]. These three characteristics are trust propensity, propensity to risk and familiarity.

\section{1) Trust Propensity}

The first characteristic of consumers is the tendency to believe in something (trust propensity). In this case, the tendency of consumers to believe in something in general, not in something specific [6]. Trust propensity is defined as a general tendency about how a person shows trust in something or someone else [6], [18], [19]. In addition, trust propensity is also defined as a fundamental difference that comes from within each individual which can influence the tendency of whether an individual will believe something or not [20]. Kee and Knox (1970) argue that trust is not only influenced by past experience, but also influenced by other factors such as one's personality [21]. Govier (1994) argues that trust propensity creates a filter that can change one's interpretation of other people's behavior [22]. Bigley \& Pearce (1998) argue that trust propensity may be the most relevant shaping factor of trust in contexts involving foreign factors [23]. Trust propensity has a significant influence on initial trust, because consumers have different levels of readiness to be able to trust others when consumers do not have sufficient information, especially in unfamiliar situations [5], [18].

\section{2) Propensity to web risk}

The second characteristic of consumers is the tendency towards risk. Risk is often seen as one of the functional variations of what will happen, and risks also relate to possibilities that can occur and are influenced by the subjective values possessed by the risk itself [24]. Researchers also recognize that risky decision making is not only influenced by rational calculations, but also influenced by individual tendencies towards the risk itself [25]. Based on this, several studies show that risk taking is more predisposing or more based on the tendency of each individual, not only influenced by situationalism [26], [27]. In addition, trends in risk taking can also influence the effects of situational characteristics of risky decisionmaking behavior [28].

3) Familiarity with E-travel Shopping

The third characteristic of consumers is familiarity. Product familiarity can be interpreted as the level of how much consumers know a product, it will make the consumers have the ability to collect, integrate and assess the relevance of the information they have about the product, which in turn can make consumers remember the product (Hutchinson \& Alba, 1987; Rao and Monroe 1988). A person's familiarity with a product arises due to the recurring experience that a person feels with a product, and familiarity is the highest level felt by consumers in relation to a product [29]. Familiarity and comfort felt by consumers, generally related to the experience felt by consumers with e-commerce (Yoon, 2009) and also with etravel shopping (Jensen, 2012). The latest evidence suggests that familiarity has a positive influence on purchase intention in e-travel shopping (Jensen, 2012).

\section{Customer Satisfaction}

The definition of customer satisfaction according to Philip Kotler et al. (2013) is a provision about how expectations from consumers can be fulfilled [30]. In line with what was conveyed by Kotler et al. (2013), Gee et al. (2008) stated that customer satisfaction in general is meeting or exceeding expectations of consumers [31]. Egan (2008) argues that customer satisfaction is an evaluation process where initial expectations and actual performance will be compared. A more complete definition of customer satisfaction is delivered by Homburg \& Giering, 2001, according to them customer satisfaction is a result of evaluations involving cognitive and emotional after consumers using the product or service that will eventually be compared with what is expected by consumers from the start [32].

\section{Hypothesis Development}

1) Initial Trust

Online travel agent companies not only increase consumer's purchase intentions but also increase consumers' desire to be able to follow the advice given by e-travel companies and also the desire to provide consumer 
sensitive information to e-travel companies, based on this statement, author followed the statement from Harrison McKnight et al., (2002) to include 3 dimensions of intentional outcomes in the research model [6]. The first dimension is purchase intention which is often used as a measure of consumer confidence in online vendors. The second dimension is the readiness of consumers to follow the advice given by online vendors, which is very important for e-travel companies. The third dimension is the desire of consumers to provide sensitive information to online vendors, such as credit card information. The willingness of consumers to provide sensitive information is crucial so that services provided by online vendors can run successfully [6]. It is estimated that only positive perceptions of initial trust can make consumers want to provide sensitive information to e-travel companies [6]. Based on the explanation above, the hypothesis proposed is:

$\mathrm{H}_{1}$ : There is a positive relationship between initial trust and the behavioral intentions.

\section{2) Trust Propensity}

As Schoorman et al., (2007) has said, the tendency of consumers to trust something (trust propensity) can increase or reduce consumer perceptions about whether other parties can be trusted or not [17]. Kim et al (2009) and also Chen and Barnes (2007) say that there is a positive relationship between trust propensity and initial online trust [33], [34]. Based on the explanation above, the hypothesis proposed by researchers is:

$\mathrm{H}_{2}$ : There is a positive relationship between trust propensity and initial trust.

3) Propensity to Web Risk

Rousseau et al. (1998) say that trust will only be important if the existing risks are known to consumers, existing risks are consumer perceptions about the possibility of something unwanted [13]. Some researchers disagree with the risk implications of behavioral intentions. While some other researchers suggest that there are mediating effects of risk on trust [35]. McKnight et al., (2002) provide the hypothesis that there are negative effects of consumer perceived perceived risk on behavioral intentions [6]. Based on the explanation above, the hypothesis proposed by researchers is:

$\mathrm{H}_{3}$ : There is a negative relationship between propensity to web risk and the behavioral intentions.

\section{4) Familiarity}

Familiarity and comfort are felt by consumers, related to the general experience that consumers get from ecommerce [33]. In line with Yoon, Jensen (2012) said that familiarity and comfort felt by consumers are also related to consumers' experience of e-travel shopping [36]. The latest evidence suggests that familiarity has a strong positive effect on purchase intention in e-travel shopping
[36]. Based on the explanation above, the hypothesis proposed by researchers is:

$\mathrm{H}_{4}$ : There is a positive relationship between familiarity with e-travel shopping and the behavioral intentions.

5) Customer Satisfaction

Henning-Thurau et al., (2002) argue that satisfaction is a key element in the process that occurs between companies and consumers [7]. Satisfaction is a key factor to better understand consumer behavior and also increase the likelihood of consumers making repeat purchases. If the company succeeds in increasing customer satisfaction, the company will be able to increase consumer loyalty [8] [11]. Based on the explanation above, the hypothesis proposed by researchers is:

$\mathrm{H}_{5}$ : There is a positive relationship between customer satisfaction and the behavioral intentions

\section{Methodology}

This research is based on previous research conducted by Jan Møller Jensen and Corinna Wagner (2018) entitled "A cross-national comparison of Millennial consumers" initial trust towards etravel website "and also research conducted by Rubens Pauluzzo and Enrico Fioravante Geretto (2017) entitled "Evaluating customers' behavioral intentions in less significant financial institutions" [37], [38]. The design of this study aims to examine the relationship between Trust Propensity and Initial Trust, and also to examine the relationship between Initial Trust, Propensity to web risk, Familiarity with e-travel shopping, Customer Satisfaction and Behavioral Intentions. The design of this study is hypothesis testing. The unit of analysis in this study is individuals who have used Traveloka services. The method used in data collection is a questionnaire distributed through online. Cross Sectional data use in this study, where researchers conduct research at one particular time.

The following model proposed by the researcher influenced by previous research.

\section{A. Measures}

Questionnaires were distributed using online survey to collect data. The development of the questionnaire was based on our literature review. The wording of the questionnaire was modified to make items fit with the research context. The questionnaires was composed of four sections. The first section of the questionnaire consists of 8 questions capturing basic information about the respondents such as gender, age, educational background etc. The second section of the questionnaires discuss about respondents' familiarity and trust propensity toward online travel agent. The first two questions of familiarity construct adopted from Chen and Barnes (2007) and also from Jensen (2012), while the last question adopted from Gefen (2000) [18], [34], [36]. The construct of trust propensity 
was measured by four statements adopted from Koufaris and Hampton-Sosa (2004) and Gefen and Straub (2004) [5].

The next section discuss about respondents' propensity toward the risk of using online travel agent website and also about respondents' initial trust toward online travel agent. Propensity to web risk was measured by four questions adopted from McKnight et al., (2002) and Bellman et al., (2004) while initial trust was measured by three questions [6]. The first two questions measure the initial trust adopted from Ou and Sia (2010), whilst the last question adopted from McKnight (2002) [6]. The last section of the questionnaires talk about respondents' satisfaction and behavioral intention toward online travel agent. Customer satisfaction was measured by three questions adopted from Oliver (1997) while behavioral intention was measured by four questions adopted from McKnight et al. (2002) [6]. Each statement was measured using Likert Scale ranging from 1 (one) to 5 (five), where 1 indicates that respondent is strongly disagree and 5 indicates that respondent is strongly agree.

\section{B. Familiarity}

1. I am familiar with travel planning on the Internet

2. I am familiar with buying airplane tickets/hotel reservations on the Internet

3. I am familiar with the Web or App interface of Traveloka

\section{Trust Propensity}

1. It is easy for me to trust a person/thing

2. I feel that people are generally well meaning
3. I feel that people are generally trustworthy

4. I feel that people are generally reliable

D. Propensity to Web Risk

1. Entering credit card information on the web is safe

2. I don't hesitate to enter my credit card information on the web

3. Entering personal information on the web is safe

4. I hesitate to enter personal information like my name, address and phone number on the web

E. Initial Trust

1. I feel this Traveloka is trustworthy

2. I would feel confident dealing with Traveloka

3. I feel that I could count on Traveloka to help with planning the best holiday

F. Customer Satisfaction

1. Service in accordance to my expectations

2. Service in accordance to my ideal service

3. Overall satisfaction

G. Behavioral Intentions

1. Given the opportunity, I would purchase from Traveloka

2. I would feel comfortable acting upon the advice given to me by Traveloka

3. I would not hesitate to use the information provided by Traveloka

4. I would be willing to provide information like my name, address and phone number to Traveloka.

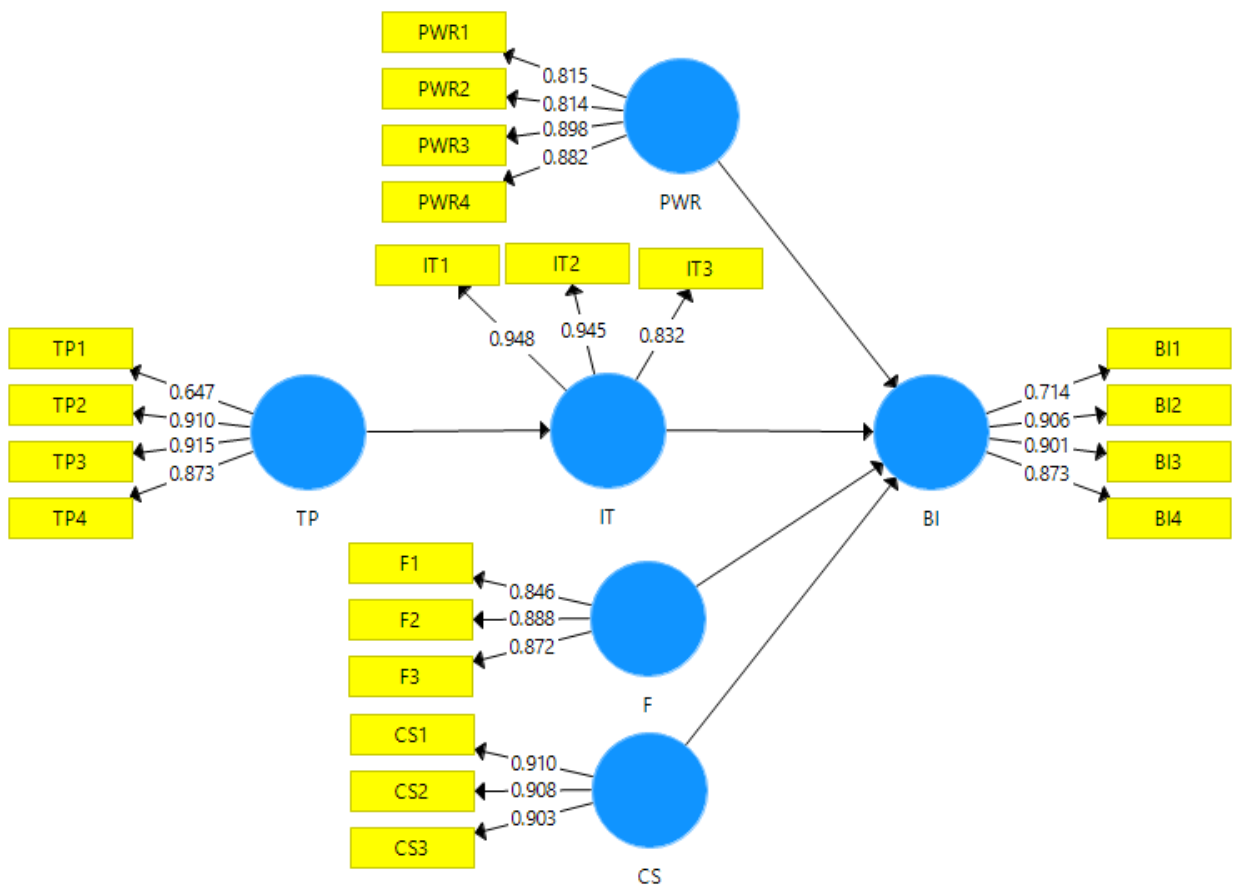

Figure 2. Factor Loading Generation X 
The $1^{\text {st }}$ International Conference on Business and Management of Technology (IConBMT)

August 3rd 2019, Institut Teknologi Sepuluh Nopember, Surabaya, Indonesia

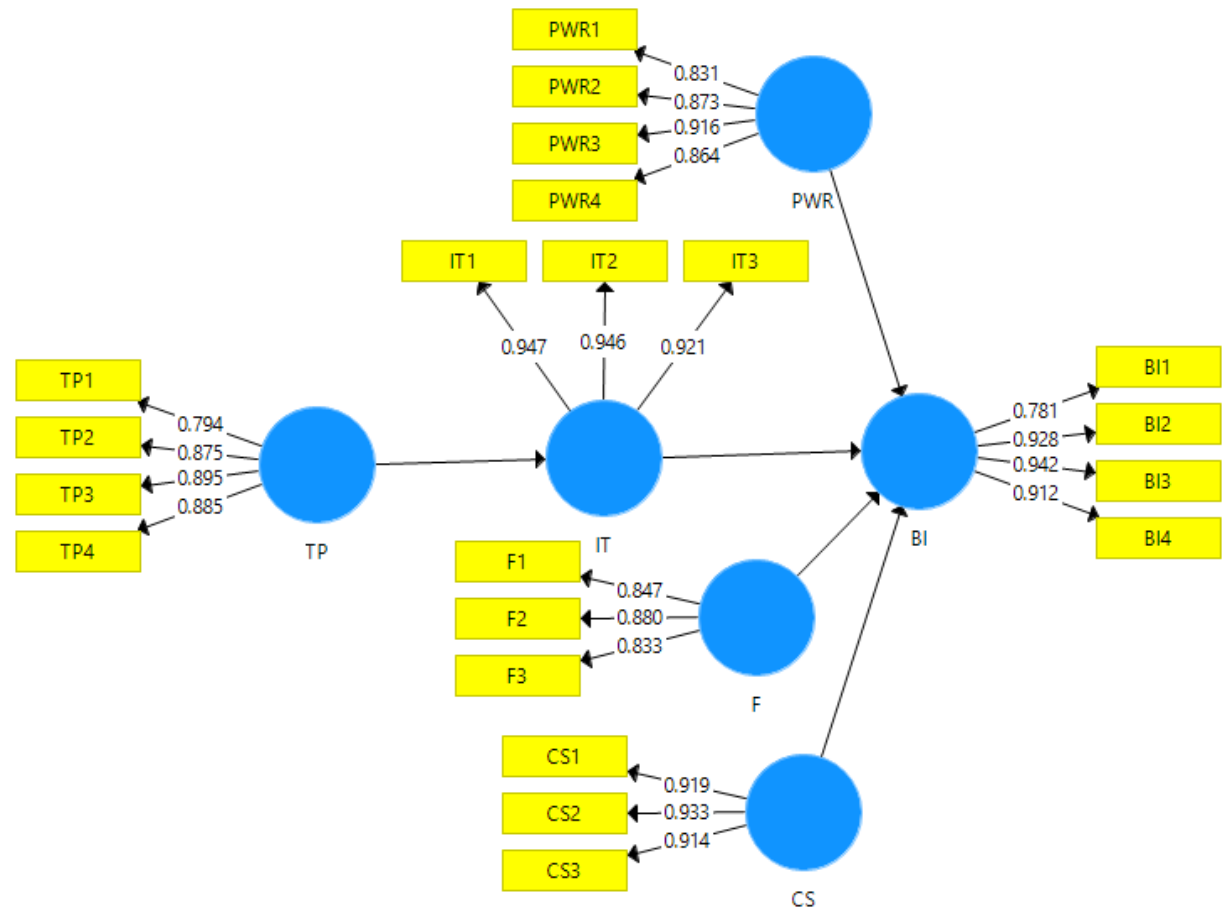

Figure 3. Factor Loading Millennial

TABLE 1. CONSTRUCT AND MEASUREMENT ITEMS

\begin{tabular}{|c|c|c|c|}
\hline Construct & & Measurement Items & Reference \\
\hline \multirow[t]{3}{*}{ Familiarity } & F1 & I am familiar with travel planning on the Internet & \multirow{2}{*}{$\begin{array}{l}\text { Chen and Barnes, } \\
\text { 2007; Jensen, } 2012\end{array}$} \\
\hline & F2 & I am familiar with buying airplane tickets/hotel reservations on the Internet & \\
\hline & F3 & I am familiar with the Web or App interface of Traveloka & Gefen, 2000 \\
\hline \multirow{4}{*}{$\begin{array}{l}\text { Trust } \\
\text { Propensity }\end{array}$} & TP1 & It is easy for me to trust a person/thing & \multirow{4}{*}{$\begin{array}{l}\text { Koufaris and } \\
\text { Hampton-Sosa, } \\
\text { 2004; Gefen and } \\
\text { Straub, } 2004\end{array}$} \\
\hline & TP2 & I feel that people are generally well meaning & \\
\hline & ТP3 & I feel that people are generally trustworthy & \\
\hline & TP4 & I feel that people are generally reliable & \\
\hline \multirow{4}{*}{$\begin{array}{l}\text { Propensity } \\
\text { to Web } \\
\text { Risk }\end{array}$} & PWR1 & Entering credit card information on the web is safe & \multirow{4}{*}{$\begin{array}{l}\text { McKnight et al., } \\
\text { 2002; Bellman et al., } \\
2004\end{array}$} \\
\hline & PWR2 & I don’t hesitate to enter my credit card information on the web & \\
\hline & PWR3 & Entering personal information on the web is safe & \\
\hline & PWR4 & I hesitate to enter personal information like my name, address and phone number on the web & \\
\hline \multirow{3}{*}{$\begin{array}{l}\text { Initial } \\
\text { Trust }\end{array}$} & IT1 & I feel this Traveloka is trustworthy & \multirow[t]{2}{*}{ Ou and Sia, 2010} \\
\hline & IT2 & I would feel confident dealing with Traveloka & \\
\hline & IT3 & I feel that I could count on Traveloka to help with planning the best holiday & McKnight, 2002 \\
\hline \multirow{3}{*}{$\begin{array}{l}\text { Customer } \\
\text { Satisfaction }\end{array}$} & CS1 & Service in accordance to my expectations & \multirow[t]{3}{*}{ Oliver, 1997} \\
\hline & CS2 & Service in accordance to my ideal service & \\
\hline & CS3 & Overall satisfaction & \\
\hline \multirow{4}{*}{$\begin{array}{l}\text { Behavioral } \\
\text { Intensions }\end{array}$} & BI1 & Given the opportunity, I would purchase from Traveloka & \multirow{4}{*}{$\begin{array}{l}\text { McKnight et al., } \\
2002\end{array}$} \\
\hline & BI2 & I would feel comfortable acting upon the advice given to me by Traveloka & \\
\hline & BI3 & I would not hesitate to use the information provided by Traveloka & \\
\hline & $\mathrm{BI} 4$ & I would be willing to provide information like my name, address and phone number to Traveloka & \\
\hline
\end{tabular}


TABLE 2.

RESPONDENTS' PROFILES

\begin{tabular}{lllll}
\hline \multicolumn{2}{c}{ Gen X, n=120 } & \multicolumn{2}{c}{ Millennials, n=197 } \\
\hline Gender & Frequency & Percent (\%) & Frequency & Percent (\%) \\
Male & 62 & $52 \%$ & 82 & $42 \%$ \\
Female & 58 & $48 \%$ & 115 & $58 \%$ \\
\hline Age & & & & \\
22 - 29 years & & & 129 & $65,5 \%$ \\
30 - 37 years & & & 68 & $34,5 \%$ \\
38 - 45 years & 60 & $50 \%$ & & \\
46 - 53 years & 60 & $50 \%$ & & \\
\hline Education & & & & \\
SMA or equal & 5 & $4 \%$ & 7 & $3 \%$ \\
D3 or equal & 8 & $7 \%$ & 9 & $5 \%$ \\
S1 or equal & 57 & $47 \%$ & 158 & $80 \%$ \\
S2 & 49 & $41 \%$ & 21 & $11 \%$ \\
S3 & 0 & $0 \%$ & 0 & $0 \%$ \\
Profession & 1 & $1 \%$ & 2 & $1 \%$ \\
\hline Occupation & & & & \\
Private employee & 25 & $21 \%$ & 79 & $40 \%$ \\
PNS & 52 & $43 \%$ & 40 & $21 \%$ \\
Entrepreneur & 20 & $17 \%$ & 12 & $6 \%$ \\
Professional & 12 & $10 \%$ & 14 & $7 \%$ \\
Student & 0 & $0 \%$ & 30 & $15 \%$ \\
Others & 11 & $9 \%$ & 22 & $11 \%$ \\
\hline \hline
\end{tabular}

\section{RESUlt AND DisCUSSION}

From 400 respondents, there are 317 respondents considered as Gen X and Millennials. Gen X with total 120 respondents, equally split with 62 of them are male or about $52 \%$ and 58 of them are female or $48 \%$. Millennials respondents with 197 in total, 82 of them are male or about $42 \%$ and 115 are female or 58\%. Majority respondents were noted to be within age group 22-29 years old with 129 respondents.

The majority of respondents from these two generation come with S1 educational background. 158 Millennials respondents are S1 or about $80 \%$ and 57 Gen X respondents are S1 or about $47 \%$ of them. Private sector is the highest sector where Millennials respondents work, with 79 of them or about $40 \%$. While Most of Gen X respondents are PNS, 52 of them or about $43 \%$.

This study was using Structural Equation Modeling (SEM) to test the model. The conceptual model in Figure 1 was translated into an SEM model with two parts: the measurement model and the structural equation model. Convergent validity and discriminant validity was conducted to test the validity of our measurement model. This test requirement is considered valid and reliability or this research can continue, and the indicator is using Average Variance Extracted (AVE), and Factor Loading.

The results for both Gen X and Millennials are were meet the convergent validity with minimum AVE 0,5 and Factor Loading 0,7. From the cross loadings table, you can see the value of each item on the construct (the table is green) greater than the cross loading value (the table is yellow). Based on the values in the Fornell-Larcker Criterion table and also the cross loadings table, it can be concluded that the Generation X and Millennial respondent data meets the requirements of discriminant validity.

According to Chin (1998), a variable can be said reliable if it has Cronbach's Alpha and Composite Reliability (CR) values in excess of 0.7 . The results of reliability testing using the help of Smart PLS software will be displayed in the table below. Based on the results, it can be seen that each variable has Cronbach's Alpha and Composite Reliability (CR) values that have exceeded the minimum limit of 0.7 according to Chin (1998), thus it can be concluded that all variables of all age groups can be stated reliably.

Having stated that the existing data are valid and reliable, the next step is to see the suitability of the overall research model (overall fit models). Refers to the values and standard values used, it can be concluded that the 
model of this study as a whole can be said to be robust or fit. If viewed in detail, all indicators correspond to the requirements with the standard values of each of these indicators, where SRMR with a value of 0.60 is in accordance with the existing standard value which requires the SRMR value below 0.80. Likewise with NFI with a value of 0.916 , above the minimum standard set which is 0.90. RMS_theta also fulfills the requirements with a value of 0.176 or can be said to be close to a value of 0 .

The results of the hypotheses tested for Gen $\mathrm{X}$ and Millenial are similar. $\mathrm{H}_{1}$ were supported where initial trust have positive relationship with behavioral intention. $\mathrm{H}_{2}$ were also supported because trust propensity have positive relationship with initial trust. $\mathrm{H}_{3}$ were also supported because propensity to web risk have negative relationship with behavioral intention. The relationship between familiarity and behavioural intention is not significant, thus $\mathrm{H}_{4}$ were not supported. Last, customer satisfaction have positive relationship with behavioural intention, so $\mathrm{H}_{5}$ were supported.

\section{E. Discussion and Conclusion}

The purpose of this paper is to examine Gen X's and Millennials' formation of trust towards online travel agent and identify the similarities and the differences in trust formation among consumers from those two generation.

The results of this study show that there's no differences on formation of trust towards online travel agent between Gen X and Millennials. The results support the effect of initial trust on behavioral intentions and the importance of consumer characteristics like trust propensity, familiarity with e-commerce and web risk in the trust building process. Initial trust felt by consumers can influence behavioral intention towards online travel agents. Only positive perceptions of initial trust can make consumers want to follow the advice given by online travel agent companies [6]. Trust propensity had proven have positive relationship with initial trust. Schoorman et al. (2007) said that the tendency of consumers to trust something (trust propensity) can increase or reduce consumer perceptions about whether other parties can be trusted or not. On the other hand, the results showed neither a significant effect of perceived web risk on behavioral intentions as proposed by McKnight et al. (2002) nor of familiarity with e- commerce on the behavioral intentions as proposed by Chen and Barnes (2007). Last, customer satisfaction had proven have positive relationship with behavioral intention. If the company succeeds in increasing customer satisfaction, it will be able to increase customer loyalty [8]-[10], [15].

\section{F. Limitation and Future Research}

This study has several limitations which also calls for further research. Begin with Initial trust, where it is a situation-specific construct depends on another aspects of the website, application, company or consumer. Other aspects that could influence the trust formation process need to be examined by future research. Future research may also examine our model on more representative samples of Millennials and Gen X in Indonesia. Other segments from another generation such as Gen $\mathrm{Z}$ and baby boomer could also be the target for future research. Other area such as occupation and religious belief can be the target for future research. Another limitation is focus of this study. This study only focus on online travel agent. Future research could use other industry or product as target.

TABLE 3

CONVERGENT VALIDITY OF GEN X

\begin{tabular}{lc}
\hline \hline & Average Variance Extracted (AVE) \\
\hline Behavioral Intention & 0,726 \\
Customer Satisfaction & 0,822 \\
Familiarity & 0,755 \\
Initial Trust & 0,828 \\
Propensity to Web Risk & 0,728 \\
Trust Propensity & 0,712 \\
\hline \hline
\end{tabular}

TABLE 4. CONVERGENT VALIDITY OF MiLLENNIALS

\begin{tabular}{lc}
\multicolumn{2}{c}{ CONVERGENT VALIDITY OF MILLENNIALS } \\
\hline \hline Behavioral Intention & 0,797 \\
Customer Satisfaction & 0,850 \\
Familiarity & 0,729 \\
Initial Trust & 0,879 \\
Propensity to Web Risk & 0,760 \\
Trust Propensity & 0,745 \\
\hline \hline
\end{tabular}

TABLE 5.

FORNELL-LARCKER CRITERION TABLE OF GEN X

\begin{tabular}{ccccccc}
\hline \hline & BI & CS & F & IT & PWR & TP \\
Behavioral Intention & 0,852 & & & & & \\
Customer Satisfaction & 0,774 & 0,907 & & & & \\
Familiarity & 0,544 & 0,546 & 0,869 & & & \\
Initial Trust & 0,761 & 0,732 & 0,561 & 0,910 & & \\
Propensity to Web Risk & 0,420 & 0,320 & 0,346 & 0,351 & 0,853 & \\
Trust Propensity & 0,354 & 0,429 & 0,349 & 0,391 & 0,493 & 0,844 \\
\hline \hline
\end{tabular}


The $1^{\text {st }}$ International Conference on Business and Management of Technology (IConBMT)

August 3rd 2019, Institut Teknologi Sepuluh Nopember, Surabaya, Indonesia

TABLE 6.

CROSS LOADINGS TABLE OF GEN $\mathrm{X}$

\begin{tabular}{ccccccc}
\hline \hline & BI & CS & F & IT & PWR & TP \\
\hline BI1 & 0,714 & 0,543 & 0,445 & 0,597 & 0,326 & 0,303 \\
BI2 & 0,906 & 0,719 & 0,528 & 0,669 & 0,311 & 0,276 \\
BI3 & 0,901 & 0,675 & 0,481 & 0,658 & 0,432 & 0,320 \\
BI4 & 0,873 & 0,689 & 0,400 & 0,667 & 0,363 & 0,311 \\
CS1 & 0,710 & 0,910 & 0,501 & 0,658 & 0,197 & 0,314 \\
CS2 & 0,696 & 0,908 & 0,471 & 0,676 & 0,325 & 0,459 \\
CS3 & 0,700 & 0,903 & 0,515 & 0,658 & 0,351 & 0,395 \\
F1 & 0,381 & 0,374 & 0,846 & 0,389 & 0,332 & 0,219 \\
F2 & 0,401 & 0,425 & 0,888 & 0,414 & 0,294 & 0,239 \\
F3 & 0,583 & 0,576 & 0,872 & 0,603 & 0,286 & 0,403 \\
IT1 & 0,710 & 0,680 & 0,530 & 0,948 & 0,428 & 0,451 \\
IT2 & 0,678 & 0,693 & 0,531 & 0,945 & 0,347 & 0,434 \\
IT3 & 0,696 & 0,626 & 0,468 & 0,832 & 0,158 & 0,154 \\
PWR1 & 0,206 & 0,222 & 0,275 & 0,183 & 0,815 & 0,462 \\
PWR2 & 0,368 & 0,296 & 0,298 & 0,257 & 0,814 & 0,438 \\
PWR3 & 0,398 & 0,292 & 0,312 & 0,345 & 0,898 & 0,424 \\
PWR4 & 0,397 & 0,265 & 0,293 & 0,359 & 0,882 & 0,389 \\
TP1 & 0,225 & 0,292 & 0,295 & 0,271 & 0,534 & 0,647 \\
TP2 & 0,337 & 0,365 & 0,268 & 0,358 & 0,425 & 0,910 \\
TP3 & 0,281 & 0,374 & 0,285 & 0,342 & 0,423 & 0,915 \\
TP4 & 0,340 & 0,408 & 0,337 & 0,342 & 0,314 & 0,873 \\
\hline \hline
\end{tabular}

TABLE 7.

FORNELL-LARCKER CRITERION TABLE OF MILLENNIAL

\begin{tabular}{ccccccc}
\hline \hline & BI & CS & F & IT & PWR & TP \\
\hline Behavioral Intention & 0,893 & & & & & \\
Customer Satisfaction & 0,921 & 0,922 & & & & \\
Familiarity & 0,604 & 0,594 & 0,854 & & & \\
Initial Trust & 0,806 & 0,785 & 0,635 & 0,938 & & \\
Propensity to Web Risk & 0,480 & 0,402 & 0,264 & 0,495 & 0,872 & \\
Trust Propensity & 0,402 & 0,360 & 0,203 & 0,298 & 0,487 & 0,863 \\
\hline \hline
\end{tabular}

TABLE 8.

CRoss LOADINGS TABLE OF MILLENNIAL

\begin{tabular}{ccccccc}
\hline \hline & BI & CS & F & IT & PWR & TP \\
\hline BI1 & 0,781 & 0,715 & 0,473 & 0,659 & 0,531 & 0,350 \\
BI2 & 0,928 & 0,866 & 0,557 & 0,744 & 0,409 & 0,369 \\
BI3 & 0,942 & 0,852 & 0,577 & 0,714 & 0,416 & 0,364 \\
BI4 & 0,912 & 0,847 & 0,544 & 0,757 & 0,374 & 0,354 \\
CS1 & 0,872 & 0,919 & 0,580 & 0,772 & 0,378 & 0,316 \\
CS2 & 0,844 & 0,933 & 0,543 & 0,687 & 0,336 & 0,329 \\
CS3 & 0,829 & 0,914 & 0,519 & 0,710 & 0,399 & 0,350 \\
F1 & 0,502 & 0,486 & 0,847 & 0,513 & 0,205 & 0,139 \\
F2 & 0,514 & 0,504 & 0,880 & 0,526 & 0,209 & 0,195 \\
F3 & 0,530 & 0,531 & 0,833 & 0,584 & 0,260 & 0,184 \\
IT1 & 0,744 & 0,722 & 0,578 & 0,947 & 0,526 & 0,307 \\
IT2 & 0,744 & 0,713 & 0,579 & 0,946 & 0,474 & 0,254 \\
IT3 & 0,778 & 0,771 & 0,626 & 0,921 & 0,394 & 0,276
\end{tabular}


The $1^{\text {st }}$ International Conference on Business and Management of Technology (IConBMT)

August 3rd 2019, Institut Teknologi Sepuluh Nopember, Surabaya, Indonesia

\begin{tabular}{c|cccccc} 
PWR1 & 0,313 & 0,260 & 0,212 & 0,338 & 0,831 & 0,384 \\
PWR2 & 0,309 & 0,250 & 0,205 & 0,328 & 0,873 & 0,378 \\
PWR3 & 0,429 & 0,377 & 0,195 & 0,469 & 0,916 & 0,439 \\
PWR4 & 0,536 & 0,443 & 0,284 & 0,517 & 0,864 & 0,467 \\
TP1 & 0,334 & 0,281 & 0,159 & 0,264 & 0,455 & 0,794 \\
TP2 & 0,361 & 0,319 & 0,201 & 0,262 & 0,377 & 0,875 \\
TP3 & 0,324 & 0,287 & 0,208 & 0,200 & 0,391 & 0,895 \\
TP4 & 0,359 & 0,343 & 0,141 & 0,285 & 0,446 & 0,885 \\
\hline \hline
\end{tabular}

TABLE 9.

RELIABILITY RESULT TEST TABLE OF GENERATION X

\begin{tabular}{ccc}
\hline \hline & Cronbach's Alpha & Composite Reliability \\
\hline Behavioral Intention & 0,871 & 0,913 \\
Customer Satisfaction & 0,892 & 0,933 \\
Familiarity & 0,843 & 0,902 \\
Initial Trust & 0,895 & 0,935 \\
Propensity to Web Risk & 0,878 & 0,914 \\
Trust Propensity & 0,858 & 0,907 \\
\hline \hline & TABLE 10. & \\
\hline \hline & Cronbach's Alpha & Composite Reliability \\
\hline \hline Behavioral Intention & 0,913 & 0,940 \\
Customer Satisfaction & 0,912 & 0,944 \\
Familiarity & 0,814 & 0,890 \\
Initial Trust & 0,931 & 0,956 \\
Propensity to Web Risk & 0,899 & 0,927 \\
Trust Propensity & 0,886 & 0,921 \\
\hline \hline
\end{tabular}

TABLE 11.

Overall Fit Model table of MillenNial

\begin{tabular}{ccc}
\hline \hline Indikator & Nilai & Standar Nilai yang digunakan \\
\hline SRMR & 0,060 & $<0,80$ \\
NFI & 0,916 & $>0,90$ \\
RMS_theta & 0,176 & Mendekati 0 \\
\hline \hline
\end{tabular}

\section{REFERENCES}

[1] S. Grabner-Kräuter and E. A. Kaluscha, "Empirical research in on-line trust: a review and critical assessment," Int. J. Hum. Comput. Stud., vol. 58, no. 6, pp. 783-812, Jun. 2003.

[2] D. L. Hoffman, T. P. Novak, and M. A. Peralta, "Information Privacy in the Marketspace: Implications for the Commercial Uses of Anonymity on the Web," Inf. Soc., 1999.

[3] Y. Truong and G. Simmons, "Perceived intrusiveness in digital advertising: Strategic marketing implications," J. Strateg. Mark., 2010.

[4] A. Beldad, M. de Jong, and M. Steehouder, "How shall I trust the faceless and the intangible? A literature review on the antecedents of online trust," Comput. Human Behav., vol. 26, no. 5, pp. 857-869, Sep. 2010.

[5] M. Koufaris and W. Hampton-Sosa, "The development of initial trust in an online company by new customers," Inf. Manag., vol. 41, no. 3, pp. 377-397, Jan. 2004.

[6] D. Harrison McKnight, V. Choudhury, and C. Kacmar, "The impact of initial consumer trust on intentions to transact with a web site: A trust building model,” J. Strateg. Inf. Syst., 2002.

[7] T. Hennig-Thurau, K. P. Gwinner, and D. D. Gremler,
"Understanding Relationship Marketing Outcomes: An Integration of Relational Benefits and Relationship Quality,” $J$. Serv. Res., 2002.

[8] H. Zameer, A. Tara, U. Kausar, and A. Mohsin, "Impact of service quality, corporate image and customer satisfaction towards customers' perceived value in the banking sector in Pakistan,” Int. J. Bank Mark., vol. 33, no. 4, pp. 442-456, 2015.

[9] J. L. Henrique and C. A. de Matos, "The influence of personal values and demographic variables on customer loyalty in the banking industry,” Int. J. Bank Mark., vol. 33, no. 4, pp. 571587, Jun. 2015.

[10] P. G. Patterson and R. A. Spreng, "Modelling the relationship between perceived value, satisfaction and repurchase intentions in a business-to-business, services context: An empirical examination,” Int. J. Serv. Ind. Manag., 1997.

[11] L. L. Berry, A. Parasuraman, and V. A. Zeithaml, "The servicequality puzzle,” Bus. Horiz., vol. 31, no. 5, pp. 35-43, Sep. 1988.

[12] R. Ladhari, "Service quality, emotional satisfaction, and behavioural intentions: A study in the hotel industry,” Manag. Serv. Qual. An Int. J., vol. 19, no. 3, pp. 308-331, 2009.

[13] D. M. Rousseau, S. B. Sitkin, R. S. Burt, and C. Camerer, "Not 
So Different After All: A Cross-Discipline View Of Trust," Acad. Manag. Rev., 1998.

[14] E. Kim and S. Tadisina, "A model of customers' trust in ebusinesses: Micro-level inter-party trust formation,” J. Comput. Inf. Syst., vol. 48, no. 1, pp. 88-104, Sep. 2007.

[15] V. A. Zeithaml, L. L. Berry, and A. Parasuraman, "The behavioral consequences of service quality,” J. Mark., vol. 60, no. 2, p. 31, Apr. 1996.

[16] I. Ajzen, "The theory of planned behavior," Organ. Behav. Hum. Decis. Process., vol. 50, no. 2, pp. 179-211, Dec. 1991.

[17] F. D. Schoorman, R. C. Mayer, and J. H. Davis, "An integrative model of organizational trust: Past, present, and future," Academy of Management Review. 2007.

[18] D. Gefen, "E-commerce: The role of familiarity and trust," Omega, 2000.

[19] C. M. Ridings, D. Gefen, and B. Arinze, "Some antecedents and effects of trust in virtual communities," J. Strateg. Inf. Syst., 2002.

[20] J. D. Mayer and P. Salovey, "Emotional intelligence and the construction and regulation of feelings," Appl. Prev. Psychol., vol. 4, no. 3, pp. 197-208, Jun. 1995.

[21] H. W. Kee and R. E. Knox, "Conceptual and methodological considerations in the study of trust and suspicion," J. Conflict Resolut., 1970.

[22] T. Govier, "Is it a jungle out there? Trust, distrust and the construction of social reality," Dialogue Can. Philos. Rev., vol. 33, no. 2, pp. 237-252, Apr. 1994.

[23] G. A. Bigley and J. L. Pearce, "Straining for shared meaning in organization science: Problems of trust and distrust," Acad. Manag. Rev., vol. 23, no. 3, p. 405, Jul. 1998.

[24] J. G. March and Z. Shapira, "Managerial Perspectives on Risk and Risk Taking,” Manage. Sci., vol. 33, no. 11, pp. 1404-1418, 1987.

[25] P. Bromiley and S. P. Curley, "Individual Differences in Risk Taking," in Wiley Series in Human Performance and Cognition. Risk-Taking Behavior, J. F. Yates, Ed. Oxford, England: John Wiley \& Sons, 1992, pp. 87-132.

[26] D. N. Jackson, L. Hourany, and N. J. Vidmar, "A fourdimensional interpretation of risk taking,” J. Pers., 1972.
[27] T. G. Plax and L. B. Rosenfeld, "Correlates of risky decisionmaking,” J. Pers. Assess., vol. 40, no. 4, pp. 413-418, Aug. 1976.

[28] S. B. Sitkins, “'On the positive effect of legalization on trust.' In Bies R. H., Lewicki R. J., Sheppard B. H. (eds.),” in Research on Negotiation in Organizations, 1995.

[29] J. W. Alba and J. W. Hutchinson, "Dimensions of consumer expertise,” Journal of Consumer Research, vol. 13. Oxford University Press, pp. 411-454.

[30] P. Kotler and G. Armstrong, "Principles of Marketing 15.," World Wide Web Internet Web Inf. Syst., 2013.

[31] R. Gee, G. Coates, and M. Nicholson, "Marketing Intelligence \& Planning Understanding and profitably managing customer loyalty Understanding and profitably managing customer loyalty,” Mark. Intell. Plan., vol. 26, no. 4, pp. 359-374, 2008.

[32] C. Homburg and A. Giering, "Personal characteristics as moderators of the relationship between customer satisfaction and loyalty? An empirical analysis," Psychol. Mark., vol. 18, no. 1, pp. 43-66, Jan. 2001.

[33] C. Yoon and S. Kim, "Developing the causal model of online store success,” J. Organ. Comput. Electron. Commer., vol. 19, no. 4, pp. 265-284, Nov. 2009.

[34] Y. H. Chen and S. Barnes, "Initial trust and online buyer behaviour,” Ind. Manag. Data Syst., vol. 107, no. 1, pp. 21-36, 2007.

[35] S. L. Jarvenpaa, N. Tractinsky, and M. Vitale, "Consumer trust in an Internet store," Inf. Technol. Manag., vol. 1, no. 1/2, pp. 45-71, 2000.

[36] J. M. Jensen, "Shopping orientation and online travel shopping: The role of travel experience,” Int. J. Tour. Res., vol. 14, no. 1, pp. 56-70, Jan. 2012.

[37] J. M. Jensen and C. Wagner, "A cross-national comparison of Millennial consumers' initial trust towards an e-travel website," Mark. Intell. Plan., vol. 36, no. 3, pp. 318-333, 2018.

[38] R. Pauluzzo and E. F. Geretto, "Evaluating customers' behavioral intentions in less significant financial institutions," Int. J. Bank Mark., vol. 35, no. 4, pp. 714-732, 2017. 